\title{
Leather Industry Solid Waste as Nitrogen Source for Growth of Common Bean Plants
}

\author{
D. Q. Lima, ${ }^{1}$ L. C. A. Oliveira, ${ }^{1}$ A. R. R. Bastos, ${ }^{2}$ G. S. Carvalho, ${ }^{2}$ J. G. S. M. Marques, ${ }^{2}$ \\ J. G. Carvalho, ${ }^{2}$ and G. A. de Souza ${ }^{2}$ \\ ${ }^{1}$ Departamento de Química, Universidade Federal de Lavras, Lavras, CP 3037 Minas Gerais, Brazil \\ ${ }^{2}$ Departamento de Ciência do Solo, Universidade Federal de Lavras, Lavras, CP 3037 Minas Gerais, Brazil
}

Correspondence should be addressed to L. C. A. Oliveira, luizoliveira@dqi.ufla.br

Received 19 January 2010; Revised 30 May 2010; Accepted 1 July 2010

Academic Editor: Yongchao Liang

Copyright ( 2010 D. Q. Lima et al. This is an open access article distributed under the Creative Commons Attribution License, which permits unrestricted use, distribution, and reproduction in any medium, provided the original work is properly cited.

\begin{abstract}
The leather industry generates large amounts of a Cr-containing solid waste (wet blue leather). This material is classified by the Brazilian Environmental Council as a category-one waste, requiring a special disposal. The patented process Br n. PI 001538 is a technique to remove chromium from wet blue leather, with the recovery of a solid collagenic material (collagen), containing high nitrogen levels. This work aimed to evaluate the residual effect of soil application of collagen on the production of dry matter, content and accumulation of $\mathrm{N}$ in common bean plants (Phaseolus vulgaris L.), after the previous growth of elephantgrass (Pennisetum purpureum Schumach.) cv. Napier, as well as to quantify the mineralization rate of $\mathrm{N}$ in the soil. The application of collagen, at rates equivalent to 16 and $32 \mathrm{tha}^{-1}$, provided greater $\mathrm{N}$ contents in the common bean plants, indicating residual effect of these rates of application; the same was observed for the rates of 4 and $8 \mathrm{tha}^{-1}$, though in smaller proportions. Higher mineralization rates of $\mathrm{N}$ collagen occurred next to 16 days after soil incubation. During the 216 days of incubation, the treatments with collagen showed higher amounts of mineralized nitrogen.
\end{abstract}

\section{Introduction}

The production of leather industry solid wastes has increased and the use of such wastes as fertilizers represents an interesting alternative for their disposal, with less potential impact to the environment [1]. The production of chromiumcontaining solid waste in tanneries has been recognized as a problem for many years, and increasing pressure from environmental authorities has demanded a solution of such a problem [2].

Historically, shavings, trimmings, and splits from the chromium tanning of hides and skins have been disposed of in landfills. However, increasing local restrictions on land disposal and the high costs of incineration have stimulated the search for alternative treatments. Many scientific groups have oriented their research to find a process to recycle and treat these wastes [3-11]. In Brazil, some research was carried out to evaluate the effect of leather industry works in the growth of cultures of commercial interest [12-15].
Castilhos et al. [13] evaluated the yields of wheat, lettuce, and radish, as well as the chemical changes in an Oxisol due to the addition of tannery wastes (primary tannery sludge; chromium-tanned leather shavings; finished leather shreds). Yields of the three crops in microplots treated with the wastes were similar to that obtained in microplots treated with lime plus NPK. Chromium concentrations in the soil and crops cultivated with tannery sludge varied from 40.7 to 71.2 and from 0.08 to $2.71 \mathrm{mg} \mathrm{kg}^{-1}$, respectively. Additions of chromium-tanned leather shavings and finished leather shreds did not decrease the crop yields or change Cr concentrations in soil or plants. Aquino Neto and Camargo [14] investigated the effects of tannery solid wastes (sludge from the liming process and the primary sludge) and $\mathrm{CrCl}_{3}$ application to two Oxisols, in a greenhouse pot experiment, and observed that lettuce growth was limited primarily by salt rather than by chromium content. Konrad and Castilhos [12] investigated the soil chemical changes and growth of corn on an Albaqualf soil, after application of tannery waste (primary 
sludge and the sludge from liming). The limed sludge increased soil $\mathrm{pH}$ (4.9 to 5.8) and calcium content (0.5 to $3.2 \mathrm{cmol}_{\mathrm{c}} \mathrm{dm}^{-3}$ ) and resulted in corn yields similar to those obtained with lime plus NPK. Chromium sludge increased soil $\mathrm{pH}$ and soil $\mathrm{N}$ ( 0.6 to $\left.0.7 \mathrm{~g} \mathrm{~kg}^{-1}\right)$. Corn yield with this treatment was similar to that obtained with NPK + lime. The $\mathrm{Cr}^{3+}$ present in the tannery sludges applied to the soil showed low mobility and presented no reactions of oxidation.

Although these research works demonstrated the efficiency of leather industry solid wastes on plants growth, if chromium is not extracted from this waste, its use can cause serious environmental problems.

The leather industry generates a large amount of a Crcontaining solid waste (wet blue leather), with approximately $30 \mathrm{~g} \mathrm{~kg}^{-1}(\mathrm{w} / \mathrm{w})$ of chromium. This material is classified by the Brazilian Environmental Council (CONAMA) as a category-one waste, one of the most dangerous and harmful wastes if discarded into the environment without any further treatment [16]. Because of this, such a material needs a special disposal, which is very expensive [17]. As a result, a new alternative for the utilization of these materials is mandatory.

To obtain leather from bovine skin, a process of tanning is necessary. Visually, the chromium tanned leather, even before receiving the finishing, is blueish and moistened. For that reason it is known as wet blue leather. Oliveira et al. [1] developed and patented (National Institute of Industrial Proprieties, Brazil-INPI—Process patented Br $\mathrm{n}$. PI 001538) a technique able to remove the chromium of the leather industry (wet blue waste $-30.000 \mathrm{mg} \mathrm{kg}^{-1} \mathrm{Cr}$ ) with the recovery of a solid collagenic material (collagen) with low-chromium $\left(125 \mathrm{mg} \mathrm{kg}^{-1}, \mathrm{Cr}\right)$ and high levels of nitrogen, with potential use in agriculture. The extraction method of chromium, based on a process developed by Oliveira et al. [1], revealed a decrease in the chromium content of approximately $99.6 \%$ in the waste material.

De Oliveira et al. [18] studied the use of leather waste after chromium extraction (collagen) as a nitrogen source to elephantgrass-Pennisetum purpureum Schumach. cv. Napier. The collagen was shown to be a good alternative source of nitrogen for the growth of elephantgrass, at rates up to $16 \mathrm{tha}^{-1}$. The wet blue leather residues did not make nitrogen available during the cultivation of elephantgrass. The application of collagen supplied the need of nitrogen by elephantgrass plants similarly to fertilization with mineral nitrogen.

This work aimed to evaluate the residual effect $\mathrm{N}$ of the collagen (the waste material obtained after chromium extraction of the wet blue waste), previously for growth of elephantgrass, on the production of dry matter, content and accumulation of $\mathrm{N}$ in bean plants (Phaseolus vulgaris L.) grown subsequently, under greenhouse conditions, as well as to quantify the net mineralization rate of $\mathrm{N}$ in soil fertilized with two rates of such solid waste.

\section{Experimental}

The study was carried out with Cr-containing leather waste (leather scraps and strips) from the Leather Industry Itaúna, in Itaúna-MG, Brazil. The chromium extraction method, based on the process developed and patented $(\mathrm{Br} \mathrm{n}$. PI 001538) by Oliveira et al. [1], revealed a reduction of approximately $99.6 \%$ of chromium in the waste, with a chromium content of $30.000 \mathrm{mg} \mathrm{kg}^{-1}$ (wet blue leather waste) being reduced to $125 \mathrm{mg} \mathrm{kg}^{-1}$ (collagen-the waste material obtained after chromium extraction of the wet blue waste).

The chromium total contents in the wet blue leather and in the collagen were measured by atomic absorption spectrophotometry (Varian AA-175 series). The removal of Cr III from wet blue leather was performed following the method developed by Oliveira et al. [1], which involves controlled temperature $\left(50^{\circ} \mathrm{C}\right)$ treatments with acid hydrolysis done with phosphoric acid, to avoid dissolution of the collagen.

The resulting material (collagen) was submitted to physical and chemical analyses according to the official methodology of Brazilian Ministry of Agriculture (Normative Instruction number 28, July, 2007). The determination of chromium in the collagen and wet blue waste samples was done according to reference methods established by the United State Environment Protection Agency [21] (Table 1). Nitrogen content in leather waste was determined by the Kjeldahl method.

The experiment with common bean plants was carried out in a greenhouse at the Soil Science Department of the Federal University of Lavras, with the plants growing in pots where plants of elephantgrass were previously grown. Collagen and wet blue treatments did not receive additional application of such residues, whereas the mineral $\mathrm{N}$ treatment received additional application of urea. The soil utilized was a typical dystrophic Yellow-Red Latosol, clayey texture, Oxisol [22], presenting chemical and physical characteristics shown in Table 2 (growth of elephantgrass) and in Table 3 (growth of common bean plants).

In a preliminary experiment, the collagen was utilized as a fertilizer for growth of elephantgrass-Pennisetum purpureum Schumach. cv. Napier [18], with the plants growing for 115 days. A randomized complete block design was used with three replicates. Pots with $5 \mathrm{~kg}$ of soil (typical dystrophic Yellow-Red Latosol clayey texture-Oxisol) were used as experimental plots and the treatments consisted of collagen addition at the rates of $10,20,40$, and $80 \mathrm{~g}$ per pot corresponding to $4,8,16$, and $32 \mathrm{tha}^{-1}$ and three additional treatments (additional 1: control; additional 2: fertilization with mineral $\mathrm{N}$ and additional 3: wet blue leather residue-without the extraction of $\mathrm{Cr}$, being this residue used only at the rate of $\left.8 \mathrm{tha}^{-1}\right)$. The additional 1 treatment, without mineral fertilizer (macro and micronutrients) and without collagen, was used as a reference for later studies of leaching. In the additional 2 treatment, a conventional fertilizer (urea) was used, at a rate equivalent to a nitrogen content in the collagen of $8 \mathrm{tha}^{-1}\left(300 \mathrm{mg} \mathrm{dm}^{-3}\right.$ of mineral nitrogen), which is the dose recommended for fertilizations in greenhouses experiments, as described by Malavolta [23].

The experiment with the common bean plants (Phaseolus vulgaris L.) was carried out to evaluate the residual effect of the collagen, with the plants growing for 84 days. Treatments with collagen did not receive additional fertilization in the 
TABLe 1: Mineral analysis of leather waste before (wet blue) and after the chromium extraction (collagen)*.

\begin{tabular}{|c|c|c|c|c|c|c|c|c|c|c|}
\hline \multirow{2}{*}{ Residue } & $\mathrm{N}$ & $\mathrm{P}$ & $\mathrm{K}$ & $\mathrm{Ca}$ & $\mathrm{Mg}$ & $\mathrm{S}$ & $\mathrm{Fe}$ & $\mathrm{Mn}$ & $\mathrm{Zn}$ & $\mathrm{Cr}$ \\
\hline & \multicolumn{2}{|c|}{$\mathrm{g} \mathrm{kg}^{-1}$} & \multicolumn{8}{|c|}{$\mathrm{mg} \mathrm{kg}^{-1}$} \\
\hline $\begin{array}{l}\text { wet blue (without } \\
\text { chromium extraction) }\end{array}$ & $104(5.19)$ & $10(0.24)$ & $0.15(0.01)$ & $0.60(0.05)$ & $0.44(0.01)$ & $12(0.41)$ & $133(0.94)$ & $2(0.14)$ & $5(0.24)$ & $30.050(5.25)$ \\
\hline $\begin{array}{l}\text { collagen (after } \\
\text { chromium extraction) }\end{array}$ & $146(3.68)$ & $26(0.47)$ & $0.14(0.01)$ & $0.48(0.02)$ & $0.08(0.01)$ & $3(0.14)$ & $70(0.82)$ & $1(0.09)$ & $10(0.09)$ & $125(0.94)$ \\
\hline
\end{tabular}

Chemical methods: Total $\mathrm{N}=$ Kjeldahl; $\mathrm{P}=\mathrm{CNA}+\mathrm{H}_{2} \mathrm{O}\left(\mathrm{P}_{2} \mathrm{O}_{5}\right) ; \mathrm{K}, \mathrm{Ca}, \mathrm{Mg}, \mathrm{S}, \mathrm{Fe}, \mathrm{Mn}$, and $\mathrm{Zn}=$ Mehlich 1 [20]; $\mathrm{Cr}=\mathrm{USEPA} 3051$ [21]. Values are the mean of three replicates. Numeric values in brackets represent SD (standard deviation).

*Adapted from De Oliveira et al. [18].

TABLE 2: Chemical and physical soil characteristics before elephantgrass cultivation.

\begin{tabular}{|c|c|c|c|}
\hline \multirow{2}{*}{ Characteristics } & \multicolumn{3}{|c|}{ Determinations* } \\
\hline & $\begin{array}{c}\text { EMBRAPA } \\
{[19]}\end{array}$ & $\begin{array}{c}\text { MEHLICH } \\
{[20]} \\
\end{array}$ & $\begin{array}{c}\text { USEPA } \\
{[21]}\end{array}$ \\
\hline $\mathrm{pH}\left(\mathrm{H}_{2} \mathrm{O}\right)$ & $5.9(0.05)$ & & \\
\hline $\mathrm{Al}^{3+}\left(\mathrm{cmol}_{\mathrm{c}} \mathrm{dm}^{-3}\right)$ & $0.0(0.02)$ & & \\
\hline $\mathrm{K}^{+}\left(\mathrm{cmol}_{\mathrm{c}} \mathrm{dm}^{-3}\right)$ & & $0.11(0.01)$ & \\
\hline $\mathrm{Ca}^{2+}\left(\mathrm{cmol}_{\mathrm{c}} \mathrm{dm}^{-3}\right)$ & $4.0(0.21)$ & & \\
\hline $\mathrm{Mg}^{2+}\left(\mathrm{cmol}_{\mathrm{c}} \mathrm{dm}^{-3}\right)$ & $2.0(0.14)$ & & \\
\hline $\mathrm{H}^{+}+\mathrm{Al}^{3+}\left(\mathrm{cmol}_{\mathrm{c}} \mathrm{dm}^{-3}\right)$ & $3.0(0.05)$ & & \\
\hline O.C. $\left(\mathrm{g} \mathrm{kg}^{-1}\right)$ & $9.0(0.08)$ & & \\
\hline $\mathrm{N}_{\text {Total }}\left(\mathrm{g} \mathrm{kg}^{-1}\right)$ & $30(0.94)$ & & \\
\hline $\mathrm{N}-\mathrm{NH}_{4}{ }^{+}\left(\mathrm{mg} \mathrm{kg}^{-1}\right)$ & $35(1.41)$ & & \\
\hline $\mathrm{N}-\mathrm{NO}_{3}{ }^{-}\left(\mathrm{mg} \mathrm{kg}^{-1}\right)$ & $26(1.25)$ & & \\
\hline $\mathrm{P}\left(\mathrm{mg} \mathrm{dm}^{-3}\right)$ & & $8.0(0.21)$ & \\
\hline $\mathrm{Cu}\left(\mathrm{mg} \mathrm{dm}^{-3}\right)$ & & $2.0(0.08)$ & $20(0.94)$ \\
\hline $\mathrm{Fe}\left(\mathrm{mg} \mathrm{dm}^{-3}\right)$ & & $3.0(0.09)$ & $\begin{array}{l}42.238 \\
(17.91)\end{array}$ \\
\hline $\operatorname{Mn}\left(\mathrm{mg} \mathrm{dm}^{-3}\right)$ & & $228(3.30)$ & $67(3.56)$ \\
\hline $\mathrm{Zn}\left(\mathrm{mg} \mathrm{dm}^{-3}\right)$ & & $34.5(1.08)$ & $20(1.70)$ \\
\hline $\mathrm{Cr}\left(\mathrm{mg} \mathrm{dm}^{-3}\right)$ & & $0.2(0.17)$ & $74(5.91)$ \\
\hline Clay $\left(\mathrm{g} \mathrm{dm}^{-3}\right)$ & $460(0.47)$ & & \\
\hline Silt $\left(\mathrm{g} \mathrm{dm}^{-3}\right)$ & $160(0.94)$ & & \\
\hline Sand $\left(\mathrm{g} \mathrm{dm}^{-3}\right)$ & $380(0.47)$ & & \\
\hline $\begin{array}{l}{ }^{*} \text { Chemical methods: } \mathrm{pH}\left(\mathrm{H}_{2}\right. \\
(\mathrm{SMP}) ; \mathrm{B} \text { (hot water); } \mathrm{S}(\mathrm{Ca} \\
\mathrm{Na}_{2} \mathrm{Cr}_{2} \mathrm{O}_{7} 0,67 \mathrm{~mol} \mathrm{~L}{ }^{-1}+\mathrm{H}_{2} \\
\text { Values are the mean of three } \\
\mathrm{SD} \text { (standard deviation). }\end{array}$ & $\begin{array}{l}1: 2.5) ; \mathrm{Ca}, \mathrm{M} \\
\left.{ }_{2} \mathrm{PO}_{4}\right)_{2} \cdot \mathrm{H}_{2} \mathrm{O} \text { i. } \\
\left.\mathrm{O}_{4} 5 \mathrm{~mol} \mathrm{~L} \mathrm{~L}^{-1}\right) \\
\text { plicates. Numer }\end{array}$ & $\begin{array}{l}\mathrm{Al}(\mathrm{KCl} 1 \mathrm{~m} \\
\text { cetic acid); } \\
\text { alues in bra }\end{array}$ & $\begin{array}{l}-1) ; \mathrm{H}+\mathrm{Al} \\
\text { (oxidation } \\
\text { ts represent }\end{array}$ \\
\hline
\end{tabular}

cultivation of common bean, whereas, the additional 2 treatment received an application of urea. Nutrient determinations were performed on the shoot, pods, grains, and roots. Samples were submitted to nitro-perchloric digestion and $\mathrm{Cr}$ contents were obtained by atomic absorption spectrophotometry (Varian AA-175 series). Nitrogen content was measured in extracts prepared through sulphuric acid digestion by the Kjeldahl method, as described by Malavolta et al. [24]. The data obtained was submitted to variance analysis by the $F$ test using the SISVAR (Analysis of Variance System) statistics program [25].
The net mineralization rate of $\mathrm{N}$ was evaluated in soil samples of the typical dystrophic Yellow-Red Latosol, clayey texture [22]. The study was set up in plastic containers with perforated lids, containing about $180 \mathrm{~g}$ of soil, and maintained in a dark environment at room temperature. Humidity was maintained at $60 \%$ of total volume of pores. Incubation lasted 216 days. A randomized complete block design was used with five replicates, consisting of two rates of collagen ( 4 and $8 \mathrm{tha}^{-1}$ ) and two of additional treatments (control-without mineral fertilization of macro and micronutrients and without collagen; and wet blue leather residue-without the extraction of $\mathrm{Cr}$, being that residue used only in the rate of $8 \mathrm{tha}^{-1}$ ). The analyses of the contents of $\mathrm{NO}_{3}{ }^{-}$and $\mathrm{NH}_{4}{ }^{+}$[26] in the soil were performed after $8,16,24,40,75,126,162$, and 216 days of incubation. The mineralization rates and the contents of $\mathrm{N}$ total for the additional 3 and treatments 4 and $8 \mathrm{tha}^{-1}$ of collagen were calculated discounting the values obtained for the additional 1 .

\section{Results and Discussion}

In the evaluation of the residual effect of the collagen fertilization applied at planting of elephantgrass on the subsequent cultivation of common bean plants, the $F$ test for the variance analysis detected a highly significant effect $(P \leq .00001)$ of the rates of the collagen, as well as of the additional treatments, on the production of shoot, pod, grains, and roots dry matter weights, and in the content and accumulation of $\mathrm{N}$ in the shoots (Figures 1, 2(a), 2(b), 3, 5, and 6, resp.).

It was observed that smaller rates of collagen (4 and $8 \mathrm{tha}^{-1}$ ) produced less common bean shoot dry matter (Figure 1). De Oliveira et al. [18] observed that in the first cultivation with elephantgrass, those rates provided the largest biomass production. The fact that those rates resulted in lower production in the bean plant cultivation was expected since $\mathrm{N}$ is one of the nutrients that is present in the harvested product, being one of the most absorbed elements by the cultures [23].

For the production of shoot dry matter, a negative quadratic response to the application of the collagen was observed, and the earlier application of collagen at the rate of $55 \mathrm{~g}$ per pot (equivalent to $22 \mathrm{tha}^{-1}$ ) provided a calculated maximum grain production of common bean plants of $16 \mathrm{~g}$ per pot (dry matter), Figure 1. In general, the tendencies of 
TABLE 3: Chemical and physical soil characteristics before common bean plants cultivation.

\begin{tabular}{|c|c|c|c|c|c|c|c|}
\hline \multirow{2}{*}{ Characteristics* } & \multicolumn{7}{|c|}{ Treatments $^{\dagger}$} \\
\hline & Additional 1 & Additional 2 & Additional 3 & 4 tha $^{-1}$ & $8 \mathrm{tha}^{-1}$ & $16 \mathrm{tha}^{-1}$ & $32 \mathrm{tha}^{-1}$ \\
\hline $\mathrm{pH}\left(\mathrm{H}_{2} \mathrm{O}\right)$ & $5.6(0.08)$ & $5.6(0.14)$ & $5.9(0.08)$ & $6.1(0.13)$ & $6.1(0.09)$ & $5.9(0.05)$ & $5.9(0.05)$ \\
\hline O.M. $\left(\mathrm{g} \mathrm{kg}^{-1}\right)$ & $8.7(0.13)$ & $8.7(0.08)$ & $8.1(0.05)$ & $9.0(0.13)$ & $8.7(0.16)$ & $8.7(0.09)$ & $8.7(0.05)$ \\
\hline $\mathrm{N}_{\text {Total }}\left(\mathrm{g} \mathrm{kg}^{-1}\right)$ & $3.1(0.05)$ & $3.1(0.13)$ & $3.2(0.09)$ & $2.9(0.08)$ & $3.0(0.08)$ & $3.0(0.09)$ & $4.0(0.21)$ \\
\hline $\mathrm{N}-\mathrm{NH}_{4}{ }^{+}\left(\mathrm{mg} \mathrm{kg}^{-1}\right)$ & $14(0.47)$ & $40(0.47)$ & $19.4(0.28)$ & $19.3(0.14)$ & $13.5(0.24)$ & $14.4(0.05)$ & $19.1(0.08)$ \\
\hline $\mathrm{N}^{-\mathrm{NO}_{3}}{ }^{-}\left(\mathrm{mg} \mathrm{kg}^{-1}\right)$ & $9.6(0.05)$ & $10.0(0.08)$ & $8.3(0.05)$ & $8.1(0.05)$ & $6.8(0.14)$ & $10.0(0.09)$ & $25.2(0.08)$ \\
\hline $\mathrm{N}_{\text {Total }}\left(\mathrm{g} \mathrm{kg}^{-1}\right)$-common bean plants harvest & $3.8(0.08)$ & $4.1(0.05)$ & $4.0(0.16)$ & $4.1(0.09)$ & $3.9(0.05)$ & $4.0(0.09)$ & $3.6(0.05)$ \\
\hline
\end{tabular}

*EMBRAPA [19].

${ }^{\dagger}$ Additional 1: soil without fertilization and without collagen; additional 2: fertilization with mineral N; additional 3: wet blue residue; 4.8 .16 and 32 tha ${ }^{-1}$ collagen.

Values are the mean of three replicates. Numeric values in brackets represent SD (standard deviation).

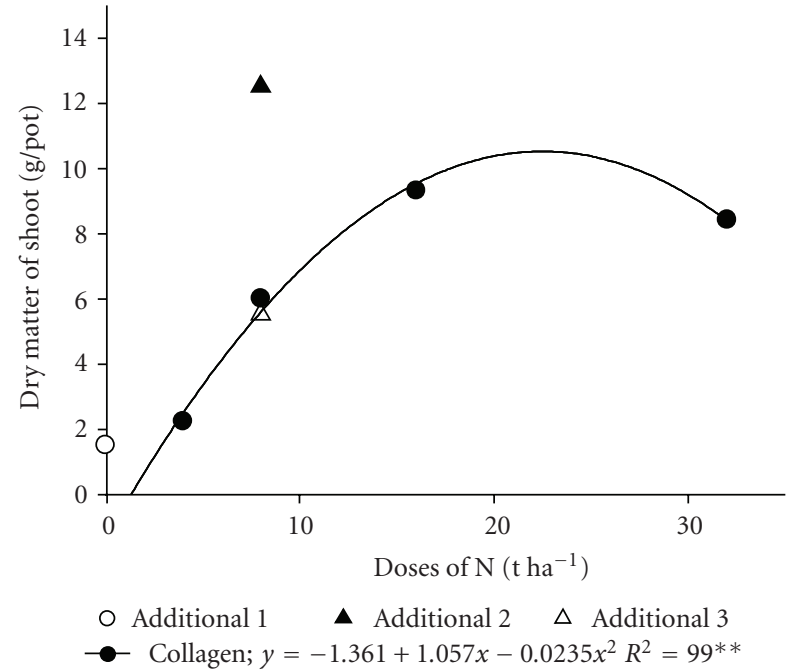

Figure 1: Production of shoot dry matter by bean plants grown for 84 days, under influence of the studied treatments (collagen - four rates; additional 1: soil without fertilization and without collagen; additional 2: fertilization with mineral $\mathrm{N}$; additional 3: wet blue residue).

dry matter production of pods, grains and roots were similar to that of shoot for all treatments (Figures 2(a), 2(b), and 3, resp.).

The additional 2 treatment showed, in general, higher dry matter production in comparison with collagen treatments. The highest production observed in the conventional fertilization treatment (additional 2) is attributed to the application of $\mathrm{N}$ in form of urea, which provided the highest production of dry matter.

It was observed that the wet blue treatment (additional 3: wet blue leather without the previous chromium extraction treatment) presented some availability of $\mathrm{N}$ to the beans plants which was not observed by De Oliveira et al. [18] in the case of elephantgrass previously cultivated in the pots of this treatment. The higher availability of $\mathrm{N}$ for bean plants in the treatment with wet blue leather is attributed to an increase of $\mathrm{N}$ mineralization during the cultivation of these plants.
These results are in agreement with those obtained in the mineralization experiment (Figure 4). It was observed that with the wet blue leather, the $\mathrm{N}$-residue practically was not mineralized. However, the same may not occur when the source of $\mathrm{Cr}$ is soluble. Castilhos et al. [27] observed, in greenhouse conditions, that the application of trivalent chromium levels upper to $20 \mathrm{mg} \mathrm{L}^{-1}$ decreased soybeans plants and nodules dry matter production, number of nodules, nitrogen fixation, and $\mathrm{P}, \mathrm{K}, \mathrm{Ca}$, and $\mathrm{Mg}$ uptake.

In the first cultivation (elephantgrass), the additional 3 (wet blue leather waste) was the treatment that provided the smallest dry matter production.

The treatments of 4 and $8 \mathrm{tha}^{-1}$ presented high mineralization rates in the period during which most cultures request larger amounts of $\mathrm{N}$ (30 to 45 days after-planting, including in the elephantgrass [18]. The mineralization rates of $\mathrm{N}$ in these treatments showed that even after that period, $\mathrm{N}$ continued being mineralized in significant amounts (verified in the cultivation in the common bean). Therefore, the found results show the potential of the collagen as a nitrogen source (Figure 4).

Chromium content in the shoot and other parts of the bean plants was shown to be found below the detection limit ( $<0.5 \mathrm{mg} \mathrm{kg}^{-1} \mathrm{de} \mathrm{Cr}$ ). Aquino Neto and Camargo [14] comment that lettuce growth was limited primarily by salt than by chromium content in tannery solid wastes applied to two Oxisols in a greenhouse pot experiment. Castilhos et al. [13] commented that the additions of chromium tanned leather shavings and finished leather shreds did not decrease the crop yields or change $\mathrm{Cr}$ concentrations in soil or plants.

For the content and accumulation of $\mathrm{N}$ in the shoot, a negative quadratic response to the rates of the collagen was observed. A significant effect was also observed for the additional treatments (Figures 5 and 6, resp.).

In general, the $\mathrm{N}$ contents in the plants supplied with collagen as well as in those from conventional fertilization wet blue residue and control treatments were below levels considered appropriate, which are from 30 to $50 \mathrm{~g} \mathrm{~kg}^{-1}$ according to [24] for bean plants, at flowering. It should be pointed out that the data shown are from the harvest time (end of cycle); therefore, they justify those smaller levels in the shoot since a large part of $\mathrm{N}$ is translocated from the leaves to the grains. It is in the initial phase that 


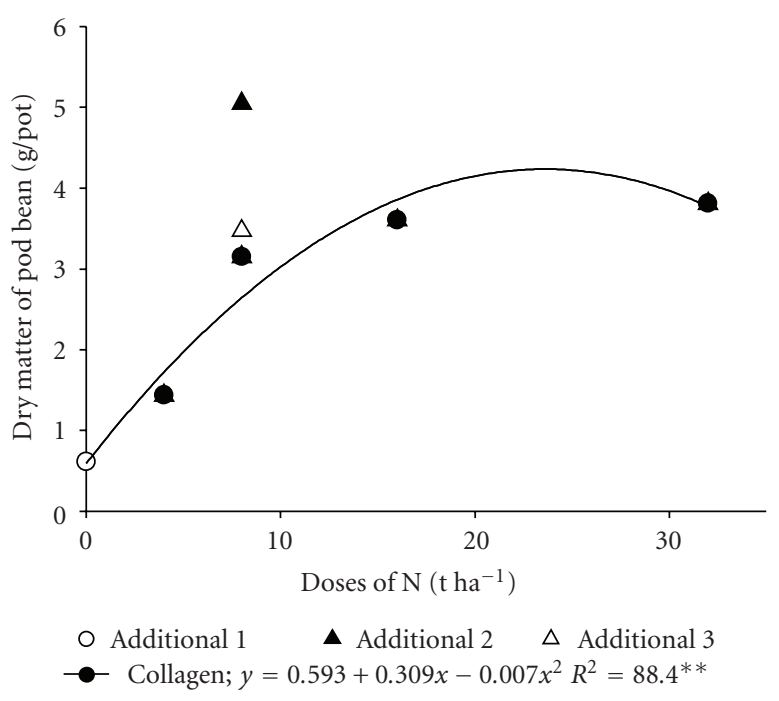

(a)

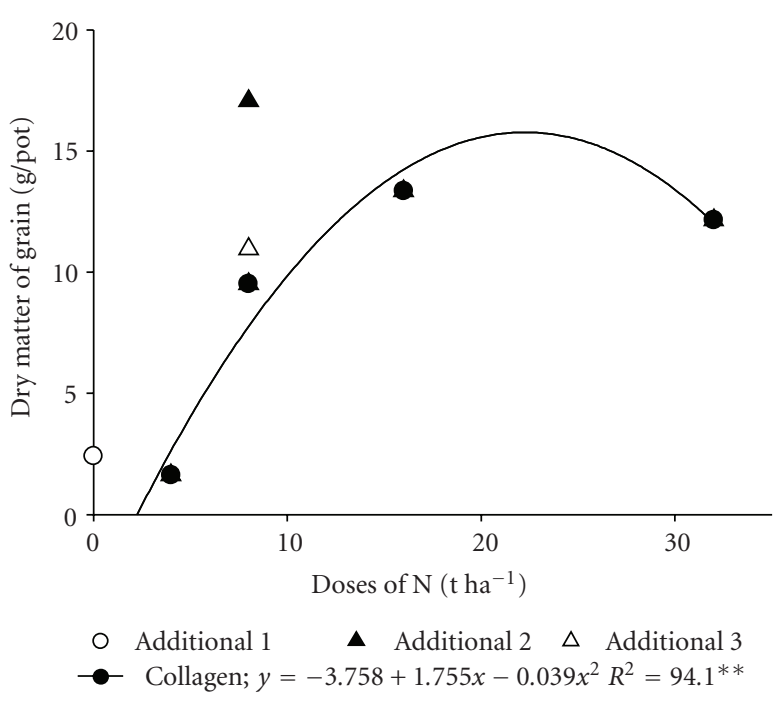

(b)

Figure 2: Production of pod dry matter of bean plants (a) and production of grain dry matter of bean plants (b) grown for 84 days, under influence of the studied treatments (collagen: four rates; additional 1: soil without fertilization and without collagen; additional 2: fertilization with mineral $\mathrm{N}$; additional 3: wet blue residue).

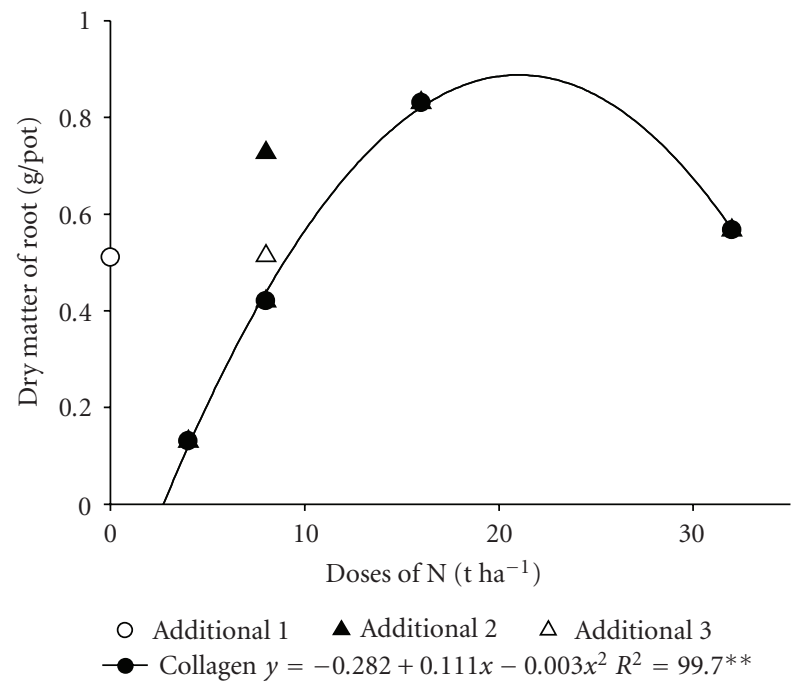

Figure 3: Production of root dry matter in bean plants grown for 84 days, under influence of the studied treatments (collagen: four rates; additional 1: soil without fertilization and without collagen; additional 2: fertilization with mineral $\mathrm{N}$; additional 3: wet blue residue).

the highest absorption occurs, and with the elapsing of the cycle, the redistribution of nitrogen to the reproductive and newer vegetative organs causes the differences in the shoot, even with the different treatments, to be minimized [23]. Nitrogen contents in bean plants were lower than in those of the elephantgrass. It is pertinent to comment that in the cultivation of the elephantgrass, the rates 16 and $32 \mathrm{tha}^{-1}$ had $\mathrm{N}$ contents above those proposed for that forage, however, for cultivation of bean plants, the presented levels were close to those of conventional fertilization.
It was noticed that the application of 16 and $32 \mathrm{tha}^{-1}$ of residue for the elephantgrass provided larger levels of $\mathrm{N}$ in the shoot of the subsequent culture (bean plant) indicating a residual effect of the fertilization at those rates; the same was observed for the rates of 4 and $8 \mathrm{tha}^{-1}$, but in smaller proportions.

The accumulation of $\mathrm{N}$ in the shoot expresses well the levels of $\mathrm{N}$ found in the shoot of the bean plants from the treatments with different rates of collagen, as well as from the additional treatments (Figure 6).

\section{Conclusions}

The collagen provided a positive response for the productivity (dry matter of shoot, pods, and grains) of the common bean plant (residual effect) similar to that of conventional mineral fertilization, presenting itself as a good nitrogen source for that culture.

The collagen application rate of $22 \mathrm{tha}^{-1}$ for growth of elephantgrass was estimated to be the optimum rate for grains production of common bean plants subsequently grown.

The collagen application of 16 and $32 \mathrm{tha}^{-1}$ for the elephantgrass provided greater $\mathrm{N}$ contents in the subsequent shoot culture (common bean plants) indicating residual effect of this; the same was observed for the rates of 4 and $8 \mathrm{tha}^{-1}$, but in smaller proportions.

Higher rates of collagen mineralization occurred next to 16 days after incubation. During the 216 days of incubation, the treatments 4 and $8 \mathrm{tha}^{-1}$ of collagen showed high amount of $\mathrm{N}$ mineralized. The wet blue leather waste (without the previous $\mathrm{Cr}$ extraction treatment) did not provide available $\mathrm{N}$ in the 216 days incubation in the soil. 


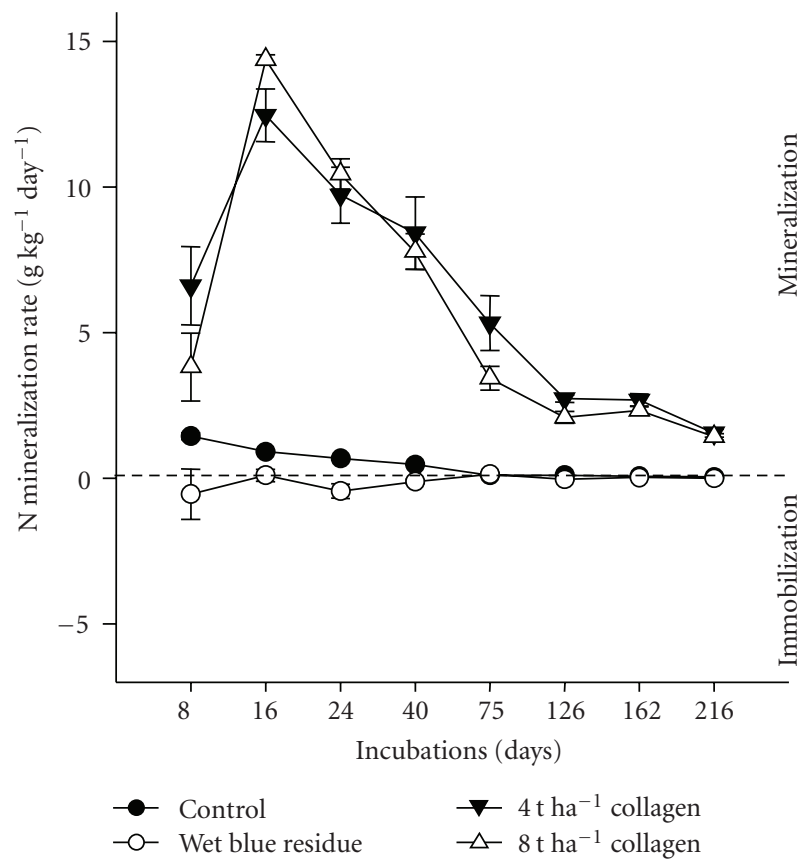

(a)

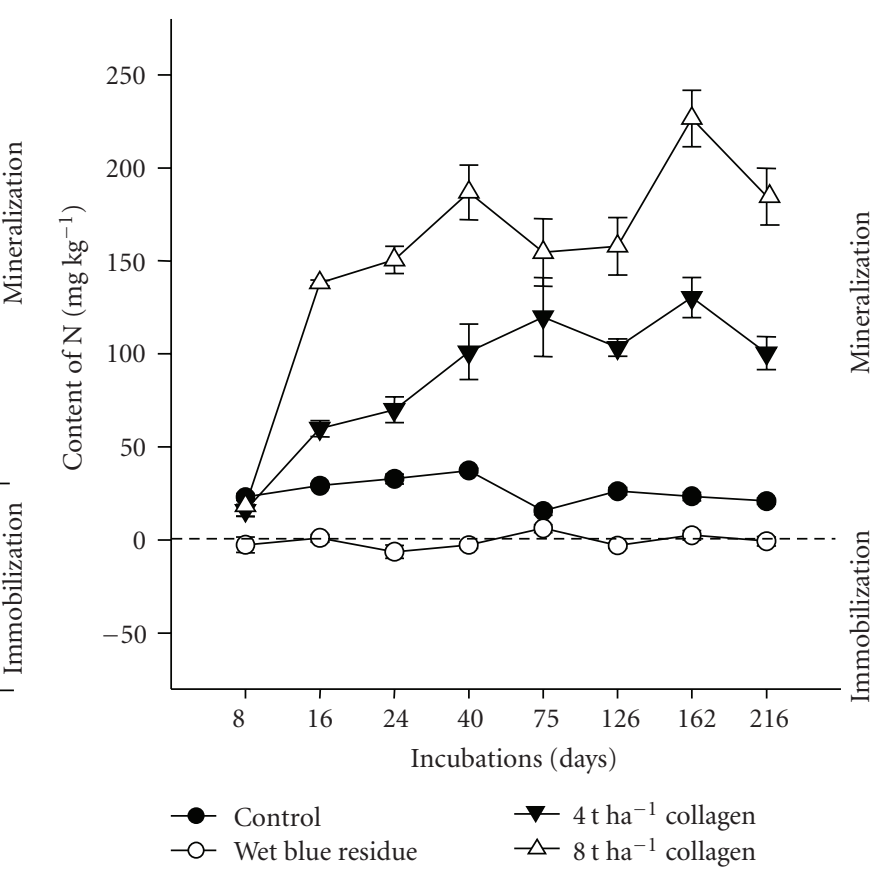

(b)

FIgURE 4: Mineralization rates (a) and the $\mathrm{N}$ mineralized $\left(\mathrm{NO}_{3}{ }^{-}+\mathrm{NH}_{4}{ }^{+}\right)$contents (b) in the treatments 4 and 8 tha ${ }^{-1}$ of the collagen and in the control and wet blue residue for 216 days incubation. Medium values of the five replicates.

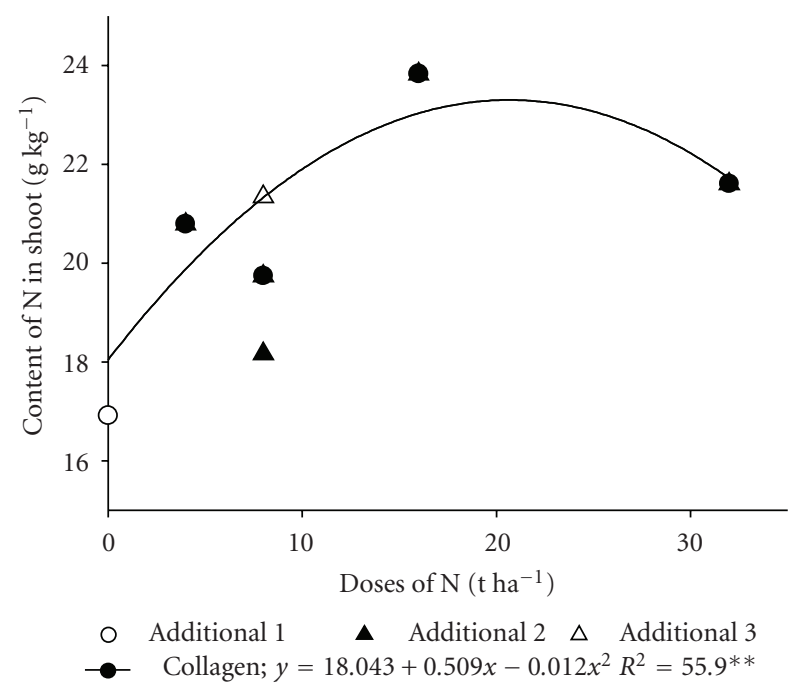

Figure 5: Content of $\mathrm{N}$ in the shoot dry matter in bean plants grown for 84 days, under influence of the studied treatments (collagen: four rates; additional 1: soil without fertilization and without collagen; additional 2: fertilization with mineral N; additional 3: wet blue residue).

\section{Acknowledgments}

The authors are grateful to the Brazilian Agencies or Organizations CNPq, FAPEMIG, CAPES, FINEP, and SEBRAE for financial support.

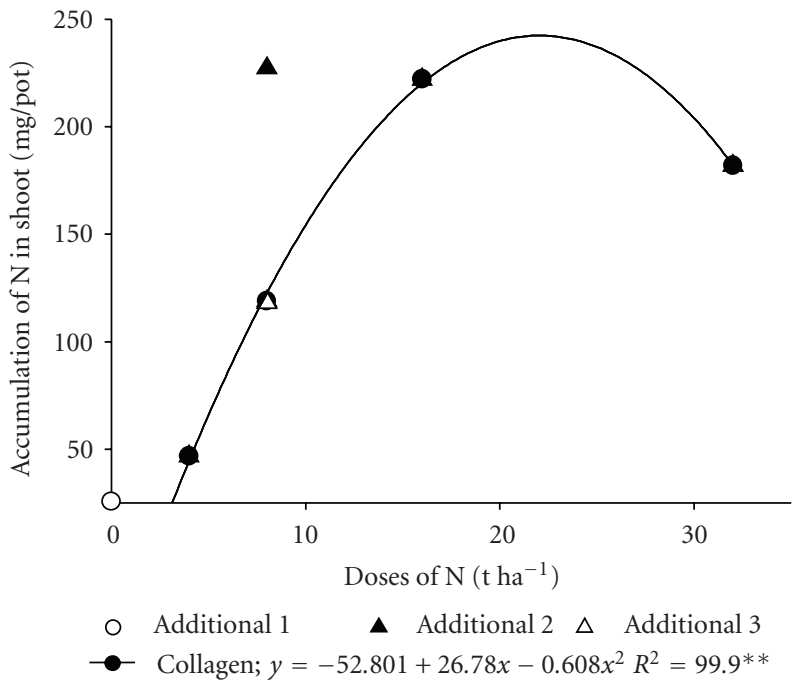

FIGURE 6: Accumulation of $\mathrm{N}$ in the shoot dry matter in bean plants grown for 84 days, under influence of the studied treatments (collagen: four rates; additional 1: soil without fertilization and without collagen; additional 2: fertilization with mineral N; additional 3: wet blue residue).

\section{References}

[1] L. C. A. Oliveira, R. M. Dallago, and I. Nascimento Filho, "Processo de reciclagem dos resíduos sólidos de curtumes por extração do cromo e recuperação do couro descontaminado," Br PI 001538, 2004. 
[2] A. Gammoun, S. Tahiri, A. Albizane et al., "Separation of motor oils, oily wastes and hydrocarbons from contaminated water by sorption on chrome shavings," Journal of Hazardous Materials, vol. 145, no. 1-2, pp. 148-153, 2007.

[3] H. Rosentreter, H. G. Klein, B. Wehling, and B. Makowka, "Processo de curtimento ao cromo de couros descarnados e depilados piquelados,” Br Pi 8804055, 1988.

[4] M. K. Compassi, "Processo de dissolução termo-química de serragem e/ou retalhos e aparas de couros curtidos ao cromo," Br PI 9202408, 1992.

[5] E. M. Brown, M. M. Taylor, and W. N. Marmer, "Production and potential uses of co-products from solid tannery waste," Journal of the American Leather Chemists Association, vol. 91, no. 10, pp. 270-276, 1996.

[6] L. F. Cabeza, M. M. Taylor, E. M. Brown et al., "Treatment of sheepskin chrome shavings. Isolation of high value protein products and reuse of chromium in the tanning process," Journal of the American Leather Chemists Association, vol. 94, no. 7, pp. 268-287, 1999.

[7] I. C. T. Silveira, D. Rosa, L. O. Monteggia, G. A. Romeiro, E. Bayer, and M. Kutubuddin, "Low temperature conversion of sludge and shavings from leather industry," Water Science and Technology, vol. 46, no. 10, pp. 277-283, 2002.

[8] C. Mu, W. Lin, M. Zhang, and Q. Zhu, "Towards zero discharge of chromium-containing leather waste through improved alkali hydrolysis," Waste Management, vol. 23, no. 9, pp. 835-843, 2003.

[9] S. P. B. Kamaludeen, K. R. Arunkumar, S. Avudainayagam, and K. Ramasamy, "Bioremediation of chromium contaminated environments," Indian Journal of Experimental Biology, vol. 41, no. 9, pp. 972-985, 2003.

[10] B. Rivela, M. T. Moreira, C. Bornhardt, R. Méndez, and G. Feijoo, "Life cycle assessment as a tool for the environmental improvement of the tannery industry in developing countries," Environmental Science and Technology, vol. 38, no. 6, pp. 1901-1909, 2004.

[11] S. Saravanabhavan, P. Thanikaivelan, J. R. Rao, B. U. Nair, and T. Ramasami, "Natural leathers from natural materials: progressing toward a new arena in leather processing," Environmental Science and Technology, vol. 38, no. 3, pp. 871-879, 2004.

[12] E. E. Konrad and D. D. Castilhos, "Alterações químicas do solo e crescimento do milho decorrentes da adição de lodos de curtume," Revista Brasileira de Ciência, Viçosa, vol. 26, pp. 257-265, 2002.

[13] D. D. Castilhos, M. J. Tedesco, and C. Vidor, "Rendimentos de culturas e alterações químicas do solo tratado com resíduos de curtume e cromio hexavalente," Revista Brasileira de Ciência do Solo, Viçosa, vol. 26, pp. 1083-1092, 2002.

[14] V. Aquino Neto and O. A. Camargo, "Crescimento e acúmulo de crômio em alface cultivada em dois latossolos tratados com $\mathrm{CrCl}_{3}$ e resíduo de curtume," Revista Brasileira de Ciência do Solo, Viçosa, vol. 24, pp. 255-235, 2000.

[15] R. H. S. Daudt, C. Gruszynski, and A. N. Kämpf, "The use of residues of wet blue leather as a growing media component," Ciencia Rural, vol. 37, no. 1, pp. 91-96, 2007.

[16] Conama, "Conselho Nacional Do Meio Ambiente," Brasília: Resolução no. 357, 1. Diário Oficial 17.05.2005 Ofício no 88.351/83, 2005.

[17] R. Aravindhan, B. Madhan, J. R. Rao, B. U. Nair, and T. Ramasami, "Bioaccumulation of chromium from tannery wastewater: an approach for chrome recovery and reuse," Environmental Science and Technology, vol. 38, no. 1, pp. 300306,2004
[18] D. Q. L. De Oliveira, K. T. G. Carvalho, A. R. R. Bastos, L. C. A. De Oliveira, J. J. G. De Sá e Melo Marques, and R. S. De Melo Pereira do Nascimento, "Utilização de resíduos da indústria de couro como fonte nitrogenada para o capim elefante," Revista Brasileira de Ciencia do Solo, vol. 32, no. 1, pp. 417-424, 2008.

[19] EMBRAPA (Empresa Brasileira de Pesquisa Agropecuária), Manual de Métodos de Análise de Solos, Ministério da Agricultura e Abastecimento, Rio de Janeiro, Brasil, 1997.

[20] A. Mehlich, Determination of $\mathrm{P}, \mathrm{Ca}, \mathrm{Mg}, \mathrm{K}, \mathrm{Na}$ and $\mathrm{NH}_{4}$, North Carolina Soil Test Division, Raleigh, NC, USA, 1953.

[21] USEPA-United States Environmental Protection Agency, "Method 3051 A: micro-wave assisted acid digestion of sediments sludges, soils and oils," in Test Methods for Evaluation Solid Waste Physical and Chemical Methods, vol. 846, pp. 1-20, Office of Solid Waste, US Environmental Protection Agency, Washington, DC, USA, 1988.

[22] EMBRAPA (Empresa Brasileira de Pesquisa Agropecuária), Sistema Brasileiro de Classificação de Solos, Ministério da Agricultura e Abastecimento, Rio de Janeiro, Brasil, 1999.

[23] E. Malavolta, Elementos de Nutrição Mineral de Plantas, Ceres, São Paulo, Brazil, 1980.

[24] E. Malavolta, G. C. Vitti, and S. A. Oliveira, Avaliação do Estado Nutricional das Plantas: Princípios e Aplicações, Potafos, Piracicaba, Brazil, 2nd edition, 1997.

[25] D. F. Ferreira, "Análises estatísticas por meio do Sisvar para Windows versão 4.0,” pp. 255-258, São Carlos, Brasil.

[26] J. M. Bremner, "Inorganic forms of nitrogen," in Methods of Soil Analysis. Part. 2, C. A. Black, Ed., pp. 1179-1237, American Society of Agronomy, Madison, Wis, USA, 1965.

[27] D. D. Castilhos, L. Bortolon, and E. S. Oliveira, "Crescimento, nodulação e absorção de nutrientes em soja sob concentrações crescentes de cromo," Magistra, Cruz das Almas, vol. 17, pp. 33-37, 2005. 

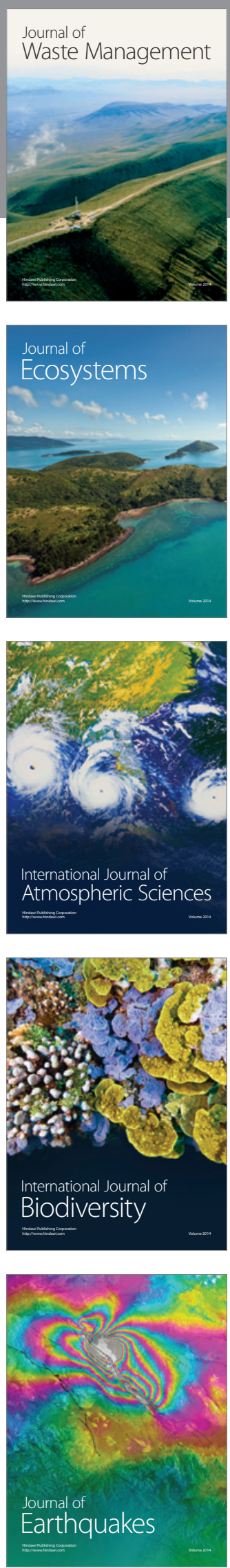
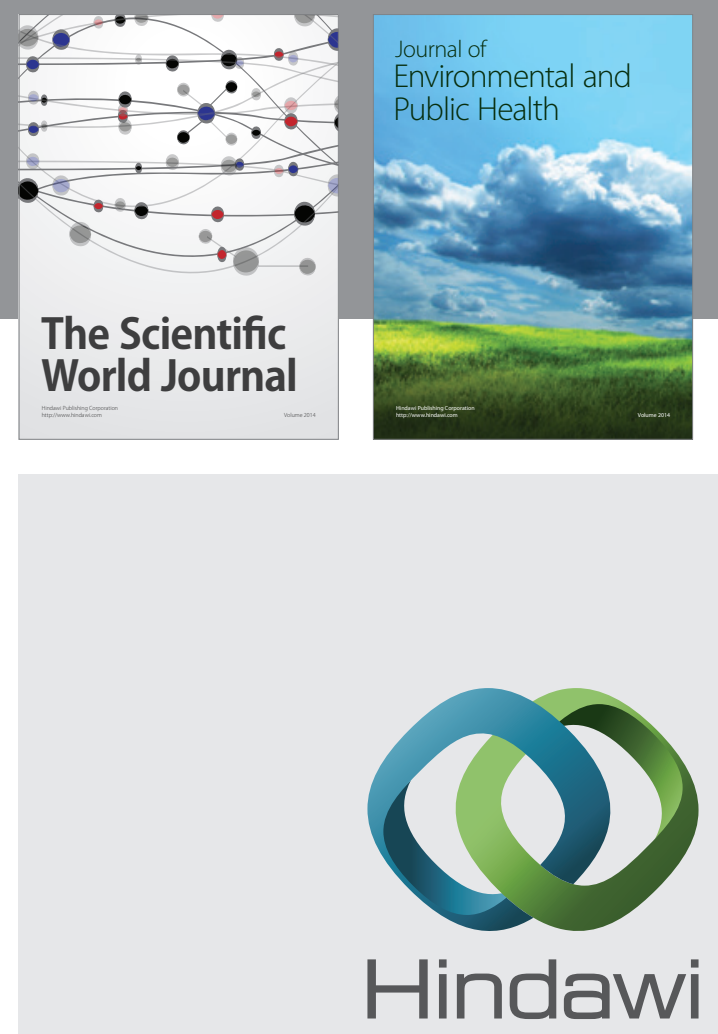

Submit your manuscripts at

http://www.hindawi.com
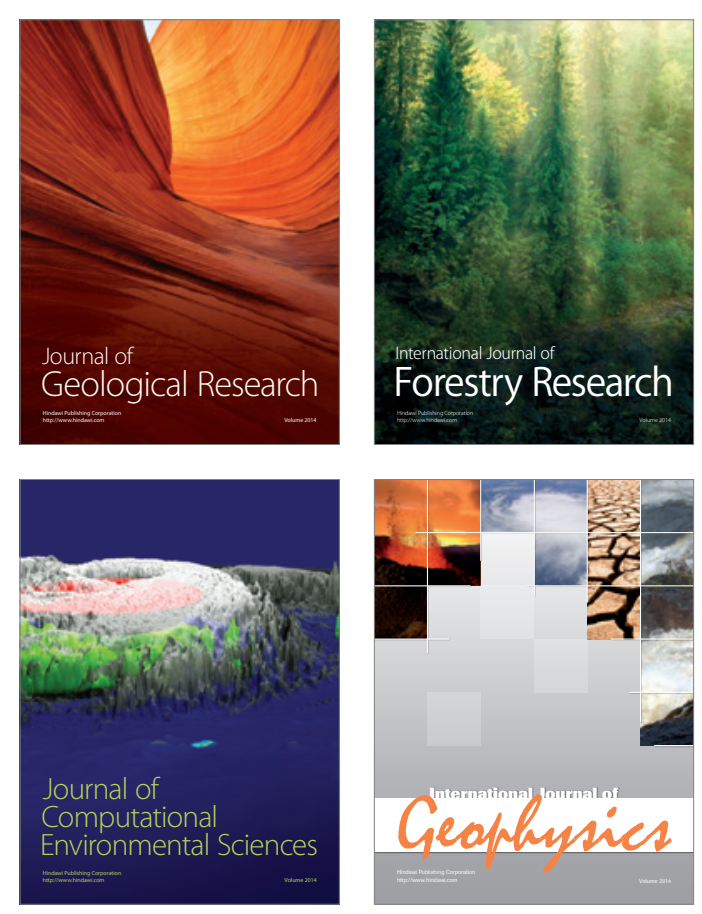
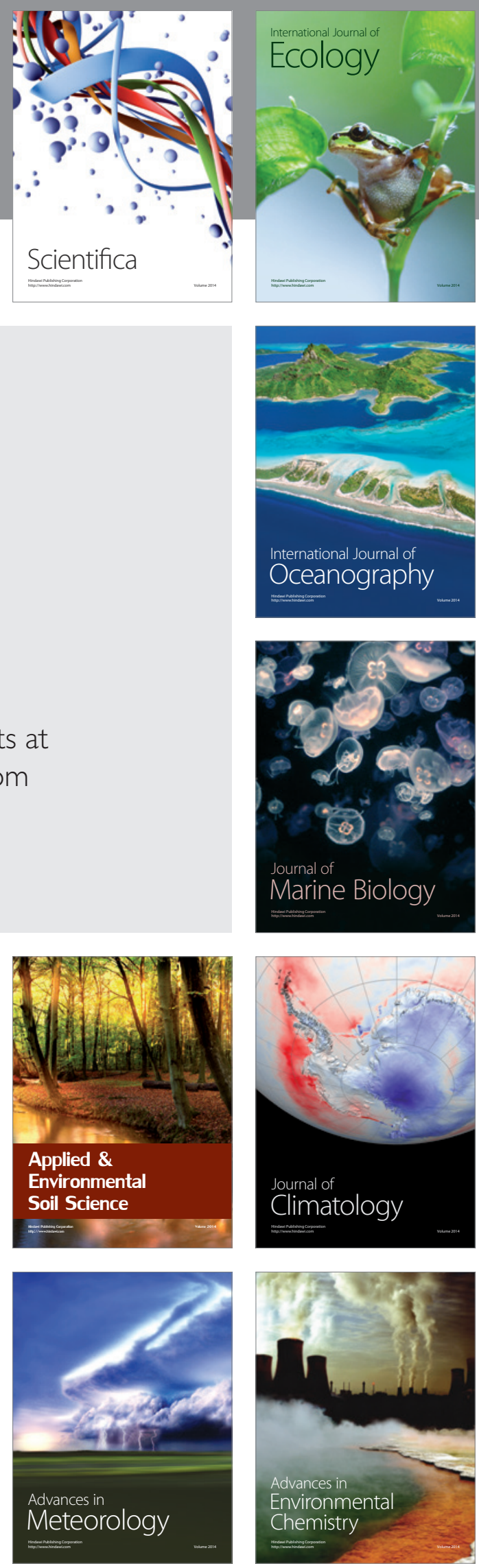